\title{
Endocrine disruption and cytotoxicity of Glyphosate and Roundup in human JAr cells in vitro
}

\author{
Fiona Young ${ }^{1 *}$, Dao Ho ${ }^{1}$, Danielle Glynn ${ }^{2}$ and Vicki Edwards ${ }^{3}$ \\ ${ }^{1}$ Department of Medical Biotechnology, Flinders University, South Australia \\ ${ }^{2}$ Department of Obstetrics and Gynaecology, University of Adelaide, Frome Road, Adelaide, South Australia \\ ${ }^{3}$ BioInnovation SA, PO Box 110, Hindmarsh, South Australia
}

\begin{abstract}
The toxicity of the active compounds in herbicides is used to determine regulatory guideline concentrations, because other components are considered inert. Glyphosate, the active molecule in the herbicide Roundup, was described as an endocrine disrupter because non-cytotoxic concentrations inhibited progesterone synthesis in vitro. Human chorioplacental JAr cells synthesise progesterone in vitro, and increase synthesis when stimulated by chorionic gonadotrophin (hCG), or the transduction molecule cAMP.

JAr cells were exposed to two Roundup formulations, and compared with the same concentrations of glyphosate $\pm \mathrm{cAMP}$, or \pm hCG for 1 , $4,24,48$ or $72 \mathrm{~h}$. The surviving viable cells were quantified using an MTT assay, and progesterone was measured in an ELISA.

hCG and cAMP stimulated progesterone synthesis as expected. Roundup was more cytotoxic than glyphosate alone; the $24 \mathrm{~h}$ EC50 was 16 mM for glyphosate, but $0.008 \mathrm{mM}$ when glyphosate was in a $7.2 \mathrm{~g} / \mathrm{L}$ Roundup formulation. Significant cytotoxicity was caused by glyphosate in Roundup (p<0.01) after $24 \mathrm{~h}$, and cytotoxicity was observed in vitro after exposure to a range of concentrations comparable to the Australian Drinking Water Guidelines. In contrast to previous reports, JAr cell death preceded decreased progesterone synthesis, and steroidogenesis was unaffected by low, non-cytotoxic concentrations of Roundup or glyphosate.

Endocrine disruption effects were secondary to cytotoxicity. Roundup was more cytotoxic than the same concentration of glyphosate alone, indicating that the other constituents of the herbicide are not inert. There is a need for in vivo studies to characterise the toxicity of glyphosate in a Roundup formulation, to facilitate reevaluation of existing public health guidelines.
\end{abstract}

\section{Introduction}

Endocrine disrupting compounds (EDCs) are defined by the U.S. Environmental Protection Agency (EPA) as being "exogenous agents that interfere with synthesis, secretion, transport, metabolism, binding action, or elimination of natural blood-borne hormones that are present in the body." The US Endocrine Society noted that key mechanisms of action for endocrine disruption include perturbation of the enzymatic pathways involved in steroid biosynthesis [1].

The rate limiting step of steroid hormone synthesis is the uptake of cholesterol from the outer to the inner mitochondrial membrane, a process mediated by the steroidogenic acute regulatory protein (StAR) $[2,3]$. Once cholesterol is inside the mitochondria it is rapidly converted to pregnenolone by cytochrome $\mathrm{P} 450$ cholesterol side chain cleavage enzyme ( $\mathrm{P} 450 \mathrm{scc}$ ), and pregnenolone is converted to progesterone by $3 \beta$-hydroxysteroid dehydrogenase $(3 \beta$-HSD) $[4,5]$. The StAR protein is acutely regulated, dependent on trophic hormone stimulation and is not an enzyme, which makes it more of a target for endocrine disruption than the steroidogenic enzymes, which are usually present in excess amounts and have long half-lives [3]. The cytochrome P450 aromatase enzyme (P450arom), which produces estradiol 17 beta $\left(E_{2}\right)$, also appears to be modulated by xenobiotics such as Roundup [6-8]. Both StAR and P450arom are upregulated by activation of the luteinising hormone/chorionic gonadotrophin receptor (LH /CG), which has cyclic adenosine monophosphate (cAMP) as an intracellular transduction molecule. The administration of a cAMP analogue, dibutrylc AMP, to the steroidogenic MA10 cell line in vitro upregulated StAR protein and stimulated a four-fold increase in synthesis of the steroid hormone progesterone [3].

The human JAr cell line was derived from a choriocarcinoma tumour of the placenta [9] and maintains placental and endocrine functions in vitro $[10,11]$ including the synthesis and secretion of progesterone $\left(\mathrm{P}_{4}\right), 17 \beta$-estradiol $\left(\mathrm{E}_{2}\right)$ and human chorionic gonadotrophin (hCG), as well as the transport of nutrients and waste products in and out of the cell: functions which are characteristic of the placental transport from mother to foetus $[10,12,13]$. The hepatobiliary-like characteristics of the JAr cell line make them a good model for studying the uptake, activation and elimination of novel compounds in vitro [11,14]. JAr cells also proliferate rapidly in vitro, with reported doubling times ranging from $15 \mathrm{~h} \mathrm{[15]} \mathrm{to} 29 \mathrm{~h} \mathrm{[16].} \mathrm{The} \mathrm{steroidogenic} \mathrm{JAr} \mathrm{cell} \mathrm{line} \mathrm{therefore} \mathrm{can}$ be used to investigate EDCs that disrupt hormone synthesis [14,17].

Glyphosate inhibits the 5-enolpyruvoylshikimate-3-phosphate synthase enzyme found in plant, but not animal aromatic amino acid synthesis pathways. This specificity to plants, along with its metabolic

Correspondence to: Dr. Fiona Young, Department of Medical Biotechnology, Flinders University, Flinders Drive, Bedford Park, Adelaide, South Australia. Tel: +61 87221 8558; E-mail: Fiona.Young@flinders.edu.au

Received: January 18, 2015; Accepted: March 29, 2015; Published: April 04, 2015 
breakdown to AMPA and thereafter to $\mathrm{CO}_{2}$, provided rationale for its development as a herbicide. The Monsanto company utilised these properties by developing transgenic maize, cotton and other crops that are resistant to glyphosate [18], thus increasing broad scale application of glyphosate in Roundup formulations. Glyphosate occurs as a hydrophilic acidic isopropylamine salt [19], which impairs its entry to lipid membrane bound cells. The herbicidal activity of glyphosate is increased by adding surfactants and other adjuvants, and a number of these mixtures are marketed under the blanket term 'Roundup' $[7,20]$. There are a number of Roundup formulations containing different concentrations of glyphosate and adjuvants such as the surfactant POEA [20]. The adjuvants and 'inert' constituents of many of these formulations have been identified, and the different Roundup formulations assigned to different classes of high, mid and low toxicity accordingly [21]. Roundup Bioforce with $360 \mathrm{~g} / \mathrm{L}$ glyphosate, and another formulation with $7.2 \mathrm{~g} / \mathrm{L}$ glyphosate, are amongst the least toxic Roundup formulations.

Manufacturers recommend that $1-2 \%$ solutions of Roundup in water should be used for agricultural applications, hence agricultural workers may be exposed to $100 \%$ concentrated solutions of approximately $2.13 \mathrm{M}$ glyphosate, and to $1-2 \%$ dilutions of the 360 $\mathrm{g} / \mathrm{L}$ Roundup formulation, which equates to exposure to $21-42 \mathrm{mM}$ of glyphosate. Roundup for domestic applications is sold in ready-touse sprays, or in concentrated forms that require dilution to similar concentrations to those used in the agricultural setting. The Australian Drinking Water Guideline [22] for glyphosate is $1 \mathrm{mg} / \mathrm{L}(0.0059 \mathrm{mM})$ because this is $10 \%$ of the acceptable daily intake and does not pose a risk to human health.

The USEPA and other jurisdictions regulate the concentration of the active ingredient glyphosate, but the adjuvants in Roundup are considered to be inert and hence are not required to be subjected to toxicological assessment $[18,20,21]$. Recent reports however, indicate that the toxicity of Roundup is not directly correlated to the concentration of glyphosate, but to the differing adjuvants and surfactants comprising various Roundup formulations $[7,8]$.

Serum-free in vitro exposure conditions were used to determine that a $2 \mathrm{~h}$ exposure to $0.15 \mathrm{mM}$ glyphosate in a $180 \mathrm{~g} / \mathrm{L}$ Roundup formulation did not affect mouse Leydig MA10 cell viability but did significantly reduce progesterone dose-dependently at non-cytotoxic concentrations [3]. Although total protein synthesis was not affected, StAR protein expression was reduced by $90 \%$, CYP 450 scc activity was halved, and progesterone synthesis was halved by the Roundup, whereas glyphosate had no effect at $100 \mu \mathrm{g} / \mathrm{mL}(0.6 \mathrm{mM})$, the highest dose tested [3].

Similarly, a short in vitro serum-free exposure to $0.015 \mathrm{mM}$ glyphosate in a $360 \mathrm{~g} / \mathrm{L}$ Roundup formulation (i.e. different adjuvents from the $180 \mathrm{~g} / \mathrm{L}$ formulation) halved the viability of human placental choriocarcinoma JEG3 cells [6]. Although the differing toxicity of the two Roundup formulations [7], and the differing sensitivity of the two cell lines (Leydig MA10 and chorioplacental JEG3) to xenobiotics prevent direct comparisons between these two studies, it can be concluded that Roundup, but not Glyphosate, reduced progesterone synthesis by inhibiting steroidogenicenzyme expression and activity, and that these endocrine disrupting effects occurred in the absence of cell death. Furthermore, endocrine disruption in these in vitro models occurred after relatively short $2-18 \mathrm{~h}$ exposures and at concentrations in the same range that agricultural workers are exposed to when applying $1-2 \%$ solutions of Roundup.
The addition of serum to in vitro cell culture systems reduced the toxicity of Roundup [6].The cell culture media were acidified to $\mathrm{pH} 5.8$ for these experiments [19]. The P450arom activity was related to $\mathrm{pH}$ : as acidity increased, enzyme activity decreased.

In serum-free $\mathrm{pH} 5.8$ in vitro culture conditions, the cytotoxic mechanism of action of Roundup and glyphosate was apoptosis followed by secondary necrosis. Roundup caused general cell membrane damage before decreasing mitochondrial membrane succinate dehydrogenase activity as measured in the MTT assay. In contrast, glyphosate did not initially reduce plasma membrane integrity, and only decreased succinate dehydrogenase activity [7].

The mixtures of glyphosate and adjuvants in Roundup have not been examined in vivo, except in one well-conducted 2 year chronic toxicity study [23,24], in which serum concentrations of estrogen and androgen in rats exposed to low concentrations of Roundup in drinking water were reported. Roundup affected the ratio of these two hormones in vivo, and there was an increase in estrogen-dependent mammary tumour formation [23].

There is only one report describing the effect of glyphosate and Roundup on progesterone synthesis [3], and this study used a cell line derived from a male mouse. Progesterone is essential for the correct regulation of the human menstrual cycle and for maintaining pregnancy, and the effect of the ubiquitous herbicide glyphosate, or Roundup, on progesterone synthesis by human female cells requires further investigation. Progesterone synthesis in the second half of the menstrual cycle in vivo is regulated by $\mathrm{LH}$, and high levels of progesterone synthesis are maintained during pregnancy in vivo by embryonic secretion of human chorionic gonadotrophin (hCG), which binds to the common transmembrane LH/hCG receptor. The effects of Roundup on progesterone secretion by human female cells, and the activity of the pituitary-derived regulatory gonadotrophin, luteinising hormone (LH), and embryo-derived chorionic gonadotrophin (CG) activity, have not previously been examined in vitro or in vivo.

Walsh et al. (2000) concluded that the inhibitory effect of Roundup on progesterone production by the male mouse Leydig MA10 cell line was mediated by downregulation of the steroidogenesis rate-limiting protein, StAR [3]. Our study aims to confirm this observation by exposing the human female chorioplacental JAr cell line (similar to the previously examined JEG cell line) to glyphosate and Roundup in vitro in order to measure cell viability and effects on steroidogenesis. Secondly, we aim to use the $\mathrm{LH} / \mathrm{hCG}$ receptor transduction molecule cAMP to upregulate progesterone synthesis. Since $\mathrm{LH} / \mathrm{hCG}$ receptor binding upregulates intracellular cAMP, which in turn upregulates StAR $[25,26]$ which stimulates progesterone synthesis by JAr cells in vitro [14], progesterone can be used to indirectly monitor StAR activity. We hypothesise that non-cytotoxic concentrations of Roundup will inhibit basal progesterone synthesis at lower concentrations than glyphosate, and that non-toxic concentrations of Roundup, but not glyphosate, will attenuate cAMP-stimulated progesterone synthesis. This hypothesis is supported by Clair et al. (2012), who found that Roundup decreased testosterone production by primary derived testicular cells at noncytotoxic concentrations [27].

This will be the first study to examine the effects of glyphosate and Roundup on progesterone production by human female cells in an in vitro cell culture system that models key aspects of reproduction in women. 


\section{Materials and methods}

\section{Chemicals}

All chemicals and reagents used in this study were HPLC grade and obtained from Sigma-Aldrich unless otherwise stated.

\section{Cell line culture}

The JAr cell line [9] was obtained from the Global Bioresource Centre $^{\mathrm{TM}}$ (ATCC) and maintained in RPMI-1640 medium supplemented with $10 \%$ heat inactivated Foetal Calf Serum (FCS, Invitrogen Corporation), sodium pyruvate $(1 \mathrm{mM})$, HEPES $(10 \mathrm{mM})$, glucose $(4.5 \mathrm{~g} / \mathrm{L})$, L-glutamine $(2 \mathrm{mM})$, sodium bicarbonate $(1.5 \mathrm{~g} / \mathrm{L})$, penicillin $(60 \mathrm{mg} / \mathrm{L})$ and streptomycin $(50 \mathrm{mg} / \mathrm{L})$, at $37^{\circ} \mathrm{C}$ in humidified atmosphere with $5 \% \mathrm{CO}_{2}$ and subcultured every 2-3 days as required. For all experiments, exponentially growing cells ( $80 \%$ confluence) were detached from flasks with $0.25 \%$ Trypsin-EDTA solution. Cell number and viability was determined using the trypan blue exclusion assay on a haemocytometer before each experiment [28].

\section{JAr cell exposure to glyphosate and Roundup}

Glyphosate N-phosphonomethyl glycine was initially dissolved in water then diluted with RPMI+10\% FCS such that the final concentration of RPMI was $97 \% \mathrm{v} / \mathrm{v}$. Two Roundup formulations $(7.2$ g/L 'Regular Roundup Weedkiller' and 360 g/L glyphosate 'Roundup Concentrate Weedkiller') were examined in this study, both obtained over-the-counter from Woolworths Pty Ltd, Australia. Information about the 'inert' ingredients was not disclosed by the manufacturers. A concentrated stock solution of each Roundup formulation was produced, such that the final concentration of RPMI was $97 \% \mathrm{v} / \mathrm{v}$. RPMI medium with $10 \%$ FCS was diluted to $97 \%$ v/v with RO water to serve as a 'vehicle' control. All media, glyphosate and Roundup solutions were adjusted to $\mathrm{pH} 7.4$.

In the first experiment, seven 1:10 serial dilutions of $7.2 \mathrm{~g} / \mathrm{L}$ glyphosate in RPMI+10\% FCS, or the same concentration of glyphosate in a $7.2 \mathrm{~g} / \mathrm{L}(45.6 \mathrm{mM})$ 'Regular Roundup Weedkiller' Roundup formulation, with or without dibutryl cyclic adenosine monophosphate (cAMP, $1 \mathrm{mM}$, activates the LH/hCG transduction pathway), were prepared. The JAr cells were pre-cultured for $2 \mathrm{~h}$ in $100 \% \mathrm{RPMI}+\mathrm{FCS}$ to facilitate adherence to the culture vessel, these media were discarded, and the cells were exposed to each concentration of glyphosate or Roundup \pm cAMP in triplicate wells for 24 or $72 \mathrm{~h}$ before media were collected for progesterone $\left(\mathrm{P}_{4}\right)$ measurement by ELISA, and the numbers of surviving viable cells were determined by MTT assay. This experiment was repeated on three separate occasions $(n=3)$.

To further explore the cytotoxicity of Roundup in the presence of hCG, JAr cells (20,000 cells per well) were pre-cultured for $2 \mathrm{~h}$ before exposure to the same seven 1:10 serial dilutions of $7.2 \mathrm{~g} / \mathrm{L}$ glyphosate in 'Regular Roundup Weedkiller' Roundup formulation \pm hCG (1000 $\mathrm{mIU} / \mathrm{mL}$ ) for $1,4,24$ or $48 \mathrm{~h}$. Each concentration or control treatment was examined in triplicate wells on three separate occasions $(n=3)$. Media were discarded and the numbers of viable cells remaining in the wells determined by MTT assay.

In the third experiment, a Roundup Weed Killer Concentrate with $360 \mathrm{~g} / \mathrm{L}$ (2.13 M) Glyphosate N-phosphonomethyl glycine + 10\% surfactant, or Glyphosate N-phosphonomethyl glycine, were diluted with RPMI+10\% FCS to $0.05 \mathrm{M}$, such that the final concentration of RPMI was $97 \% \mathrm{v} / \mathrm{v}$. Each $0.05 \mathrm{M}$ stock solution was diluted in RPMI $+10 \%$ FCS medium to generate solutions of $5 \times 10^{-6} \mathrm{M}, 5 \times 10^{-5} \mathrm{M}, 1 \times 10^{-4} \mathrm{M}$,
$2.5 \times 10^{-4} \mathrm{M}, 5 \times 10^{-4} \mathrm{M}, 1 \times 10^{-2} \mathrm{M}$. The JAr cells were preincubated for $2 \mathrm{~h}$ before exposure to glyphosate, or the same concentration of glyphosate in Roundup concentrate formulation, for $24 \mathrm{~h}$. Each concentration or control treatment was examined in triplicate wells on three separate occasions $(n=3)$. The media were collected for progesterone $\left(P_{4}\right)$ measurement by ELISA, and the numbers of surviving viable cells were determined by MTT assay.

\section{MTT cytotoxicity assay}

Thiazolyl blue tetrazolium bromide (MTT) was dissolved in sterile PBS to give a final concentration of $5 \mathrm{mg} / \mathrm{ml}$. The MTT assay was carried out by modification of the original Mosmann (1983) assay [29,30]. Standard curves were generated for each replicate experiment, which consisted of 6 serial dilutions spanning 0-100,000 cells per well in 96 well plates. Each of the 6 cell concentrations was examined in 6 replicate wells. JAr cells in the standard curve plates were incubated for $24 \mathrm{~h}$ before media were discarded and the number of viable cells per well determined.

For the MTT assay the stock MTT was diluted in RPMI + 10\% FCS to $0.5 \mathrm{mg} / \mathrm{ml}$. Culture and treatment media were discarded and $100 \mu \mathrm{l}$ MTT were added to each treatment or standard curve well for $1 \mathrm{~h}$ at $37^{\circ} \mathrm{C}+5 \% \mathrm{CO}_{2}$. After this, $80 \mu \mathrm{l}$ of $20 \%$ SDS in $0.02 \mathrm{M} \mathrm{HCl}$ were added to each well for $1 \mathrm{~h}$ at room temperature. The absorbance was measured at $570 \mathrm{~nm}$, with reference absorbance $630 \mathrm{~nm}$, using an automatic spectrophotometer with KC Junior software.

\section{Progesterone enzyme linked immunosorbent assay (ELISA)}

The primary antibody against progesterone $\left(\mathrm{P}_{4}\right)$ was used to coat the wells of a Maxisorb 96-well ELISA plate (Nunc). 'Blank' ELISA control wells contained $50 \mu$ l ELISA Immuno Assay (EIA) buffer but no primary antibody, whereas the reference standard wells contained $25 \mu \mathrm{l}$ purified $\mathrm{P}_{4}(0-4 \mathrm{ng} / \mathrm{ml})$ prepared in RPMI 1640 medium, and the test wells contained $25 \mu$ l conditioned cell culture medium. $25 \mu \mathrm{l}$ glyphosate and Roundup solutions in RPMI + 10\% FCS $\left(5 \times 10^{-6} \mathrm{M}, 5 \times 10^{-}\right.$ ${ }^{5} \mathrm{M}, 1 \times 10^{-4} \mathrm{M}, 2.5 \times 10^{-4} \mathrm{M}, 5 \times 10^{-4} \mathrm{M}, 1 \times 10^{-2} \mathrm{M}$ ) were also added to single test wells to determine if the herbicides interfered with the ELISA. The standard and test wells had $25 \mu$ l EIA buffer added, then all the wells had $50 \mu$ horseradish peroxidase (HRP) conjugated to $\mathrm{P}_{4}$ added before incubation at room temperature for 100 minutes. After washing, 100 $\mu \mathrm{l}$ of 2,2'-azino-bis(3-ethylbenzothiazoline-6-sulphonic acid) (ABTS), hydrogen peroxide and substrate buffer were added to each well for one hour or until the highest standards reached an absorbance of 1.0. Absorbance was read at primary wavelength $405 \mathrm{~nm}$, and reference wavelength $540 \mathrm{~nm}$ using KC Junior software. Hormone concentration in test wells was calculated by comparison with the standard curve. Coefficients of variation for this ELISA were described previously [14].

\section{Statistical analysis}

The numbers of viable cells per well after $24 \mathrm{~h}$ incubation in $97 \%$ and $100 \%$ RPMI $+10 \%$ FCS were compared using a 2-tailed unpaired Students T-test with significance assigned at $\mathrm{p}<0.05$. The cytotoxicity and the hormone values were subjected to 1-way ANOVA and Tukey post-hoc test, or to 2-way ANOVA with Bonferroni post-hoc test, with significance assigned at $\mathrm{p}<0.05$. The EC50 values for cytotoxicity and hormone synthesis were determined using GraphPad Prism.

\section{Results}

The numbers of viable JAr cells in the 97\% RPMI+10\% control medium were $4810 \pm 775$ cells per well (mean \pm stdev) after $24 \mathrm{~h}$ in vitro 
culture (Figure 1), and $33364 \pm 6249$ cells per well after $72 \mathrm{~h}$ culture. The addition of cAMP had no significant effect on JAr cell proliferation after $24 \mathrm{~h}(4787 \pm 1432)$ or $72 \mathrm{~h}(21025 \pm 3309)$. The highest concentration of glyphosate tested $(720 \mathrm{mg} / \mathrm{L})$ did not affect JAr cell viability whereas the highest concentration of Roundup tested (containing $720 \mathrm{mg} / \mathrm{L}$ glyphosate) killed all the JAr cells after 24 and $72 \mathrm{~h}$ ( $\mathrm{p}<0.001$, Figure 1). This formulation of Roundup caused significant cytotoxicity after a $24 \mathrm{~h}$ exposure to $0.72 \mathrm{mg} / \mathrm{L}(\mathrm{p}<0.01)$. The cell viability EC50 for exposure to the $7.2 \mathrm{~g} / \mathrm{L}$ formulation of Roundup was $1.3 \mathrm{mg} / \mathrm{L}$ and $0.9 \mathrm{mg} / \mathrm{L}$ after $24 \mathrm{~h}$ for basal and cAMP-stimulated cells respectively, and $0.29 \mathrm{mg} / \mathrm{L}$ after $72 \mathrm{~h}$ for both basal and cAMP-stimulated cells.

Basal progesterone production by JAr cells cultured in 97\% RPMI and $10 \%$ FCS was $1.46 \pm 0.2 \mathrm{ng} / \mathrm{mL}$ after $24 \mathrm{~h}$, and $8.32 \pm 1.5 \mathrm{ng} / \mathrm{mL}$ after $72 \mathrm{~h}$ (Figure 2). Cyclic AMP significantly stimulated progesterone production to $1.97 \pm 0.3(\mathrm{p}<0.01)$ and $14.89 \pm 3 \mathrm{ng} / \mathrm{mL}(\mathrm{p}<0.001)$ after 24 and $72 \mathrm{~h}$ respectively. Glyphosate did not affect basal or cAMP stimulated progesterone synthesis after 24 or $72 \mathrm{~h}$ exposure, but 0.072 $\mathrm{mg} / \mathrm{L}$ Roundup significantly reduced basal $(1.18 \pm 0.13)$ and cAMPstimulated $(1.74 \pm 0.14)$ progesterone synthesis $(\mathrm{p}<0.05)$ after $24 \mathrm{~h}$ exposure. Exposure to $0.72 \mathrm{mg} / \mathrm{L}$ Roundup for $72 \mathrm{~h}$ had no effect on basal progesterone synthesis, but significantly reduced cAMPstimulated progesterone synthesis to $12 \pm 1.6 \mathrm{ng} / \mathrm{mL}(\mathrm{p}<0.01)$. The IC50 values for basal and cAMP-stimulated progesterone synthesis after $24 \mathrm{~h}$ exposure to Roundup were 0.2 and $0.8 \mathrm{mg} / \mathrm{L}$ respectively, and $1.1 \mathrm{mg} / \mathrm{L}$ and $1.4 \mathrm{mg} / \mathrm{L}$ for basal and cAMP stimulated progesterone production respectively after $72 \mathrm{~h}$ exposure.

The cytotoxicity caused by Roundup was not affected by hCG (2-way ANOVA, Figure 3). A $1 \mathrm{~h}$ exposure to $72 \mathrm{mg} / \mathrm{L}(0.42 \mathrm{mM})$ glyphosate in Roundup formulation caused significant cytotoxicity, and exposure to $0.042 \mathrm{mM}$ caused significant cytotoxicity after $4 \mathrm{~h}$

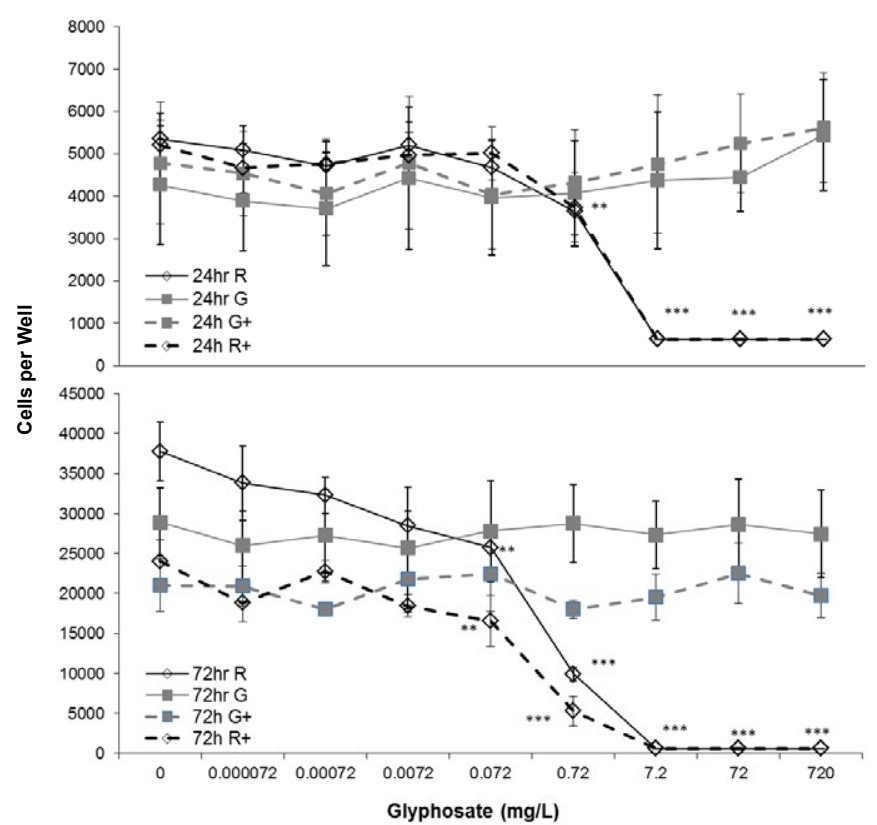

Figure 1. Effect of Glyphosate or Roundup ( $7.2 \mathrm{~g} / \mathrm{L})$ on JAr cell viability.

Human JAr cells were exposed to glyphosate $(\square)$ or Roundup $(\diamond$, formulation contained $7.2 \mathrm{~g} / \mathrm{L}$ glyphosate) \pm cAMP (----+----) in triplicate wells in 96 well plates on three separate occasions $(\mathrm{n}=3)$ for $24 \mathrm{~h}$ or $72 \mathrm{~h}$. The mean \pm stdev numbers of surviving cells in each well were determined in an MTT assay, by comparison with a standard curve generated for each experimental replicate. Data analysed by 2-way ANOVA with Tukey post-hoc test, and difference from controls shown; Roundup $\mathrm{p}<0.01 * *, \mathrm{p}<0.001 * * *$.

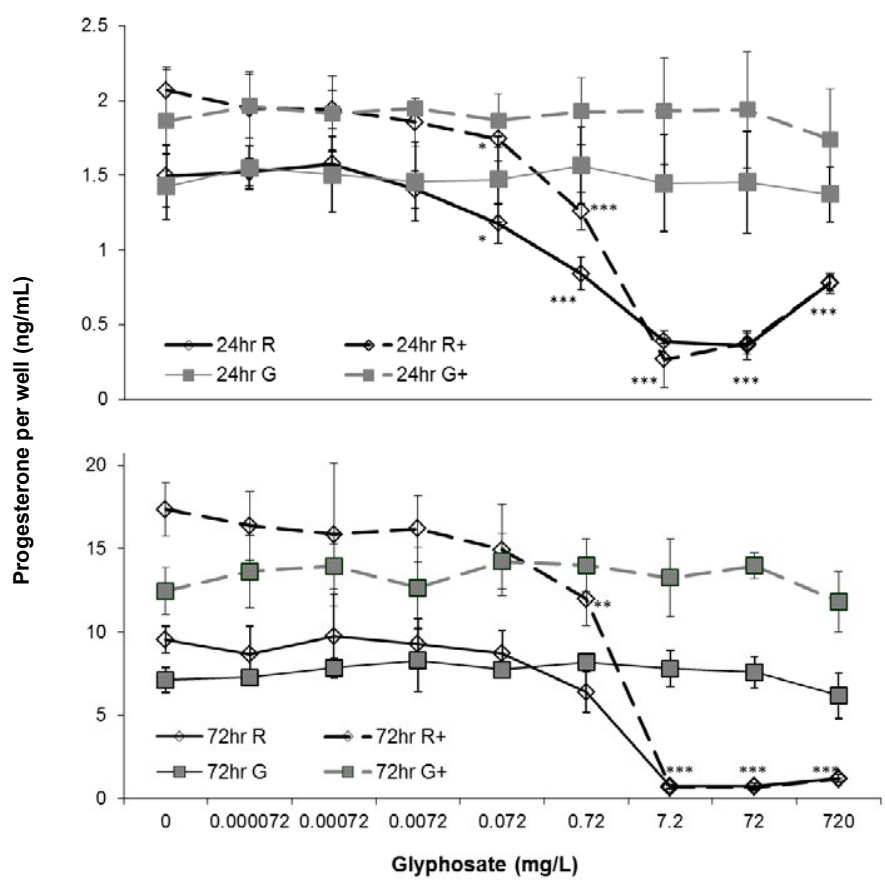

Figure 2. Effect of Glyphosate or Roundup (7.2 g/L) on JAr cell Progesterone synthesis.

Human JAr cells were exposed to glyphosate $(\square)$ or Roundup $(\diamond$, formulation contained $7.2 \mathrm{~g} / \mathrm{L}$ glyphosate) in triplicate wells in 96 well plates on three separate occasions $(\mathrm{n}=3)$ for $24 \mathrm{~h}$ or $72 \mathrm{~h}$ with (- -+- -) or without cAMP. The progesterone concentration $(\mathrm{ng} / \mathrm{mL})$ in each well was determined in an ELISA assay, by comparison with a standard curve, and the mean \pm stdev concentration of three independent experimental replicates $(n=3)$ shown. Data analysed by 2-way ANOVA with Bonferroni post-hoc test to compare cAMP-stimulated or basal progesterone secretion against glyphosate dose, and difference from control shown; $\mathrm{p}<0.05^{*}, \mathrm{p}<0.01^{* *}, \mathrm{p}<0.001 * * *$.

(Figure 3). The EC50 value after a $24 \mathrm{~h}$ exposure to Roundup and hCG was $0.007 \mathrm{mM}$, similar to the $0.005 \mathrm{mM}$ EC50 value after $24 \mathrm{~h}$ exposure to Roundup and cAMP (Table 1).

In a second series of experiments using a Roundup formulation with $320 \mathrm{~g} / \mathrm{L}$ glyphosate, there was no difference in JAr cell viability when cultured in $100 \%$ or $97 \%$ RPMI media (Figure 4), and the JAr cell numbers increased from 40000 to $71946 \pm 8792$ cells per well $(n=7)$ in $24 \mathrm{~h}$. Roundup caused significant cytotoxicity at $0.1 \mathrm{mM}(\mathrm{p}<0.05)$, whereas glyphosate caused cytotoxicity at a concentration that was two orders of magnitude higher $(10 \mathrm{mM}, \mathrm{p}<0.001)$. The cytotoxicity IC50 values were 16 and $0.13 \mathrm{mM}$ for glyphosate and Roundup respectively. Progesterone synthesis was significantly decreased by 2.5 $\mathrm{mM}$ Roundup $(\mathrm{p}<0.01)$ and $50 \mathrm{mM}$ Glyphosate $(\mathrm{p}<0.01)$. Cell death was caused by lower concentrations of Glyphosate or Roundup than those that inhibited progesterone production (Figure 4).

\section{Discussion}

Human reproductive cells were exposed to two different formulations of Roundup, and their effects on basal, cAMP- and hCGstimulated cell viability and progesterone production were examined for the first time. The in vitro model included serum and was conducted at physiological $\mathrm{pH}$. Transformed cell lines are less sensitive than primary-derived cells in vitro $[7,20]$, and these experiments therefore provide conservative estimates for potential cytotoxicity in vivo. 


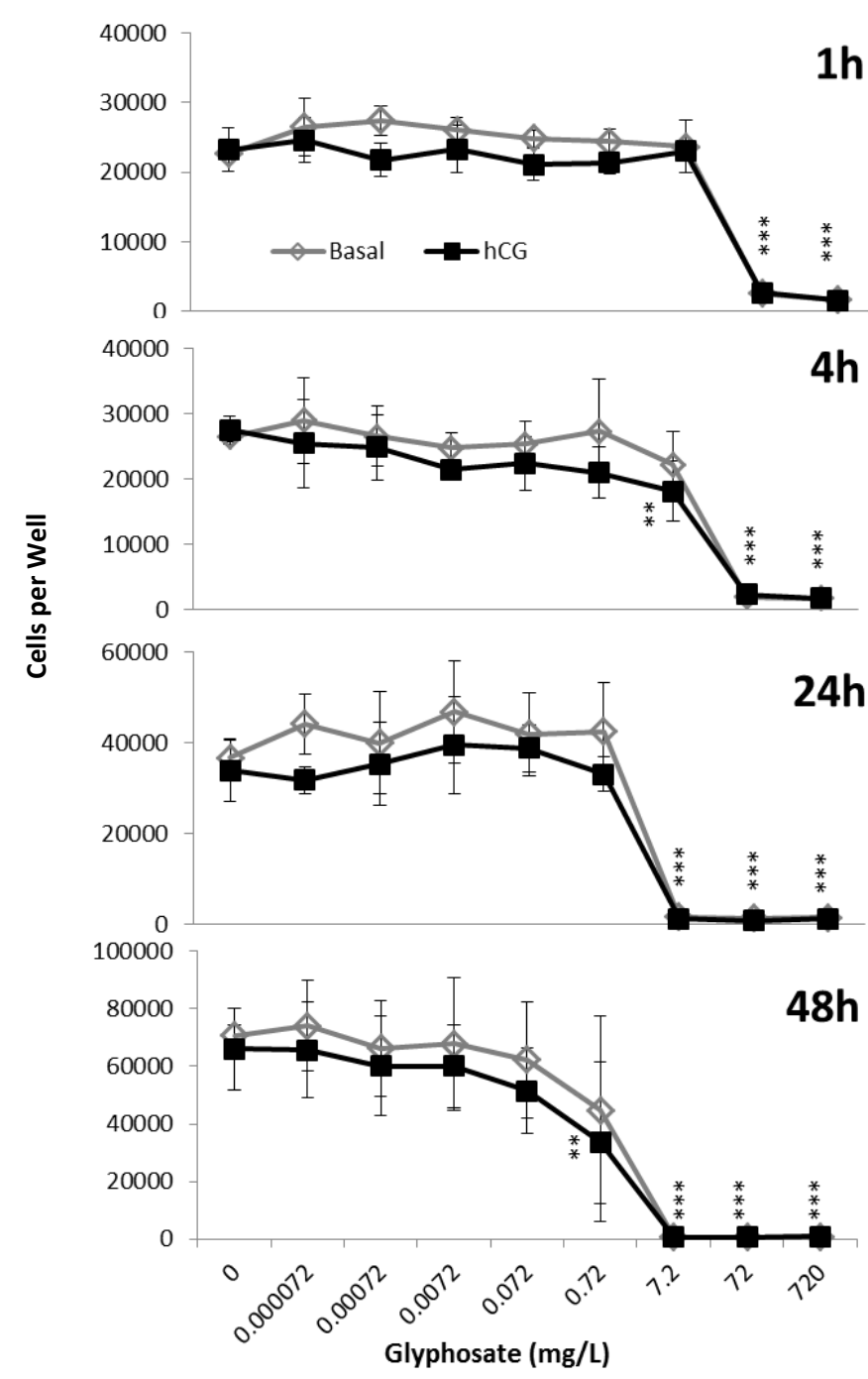

Figure 3. Effect of Roundup (7.2 g/L) and hCG on JAr cell viability.

Human JAr cells were exposed to Roundup (formulation contained $7.2 \mathrm{~g} / \mathrm{L}$ glyphosate) with $($ a) or without $(\diamond)$ human chorionic gonadotrophin $(\mathrm{hCG}, 1000 \mathrm{mIU} / \mathrm{mL})$ in triplicate wells in 96 well plates on three separate occasions $(n=3)$ for $1,4,24$ or $48 \mathrm{~h}$. The mean \pm stdev numbers of surviving cells in each well were determined in an MTT assay, by comparison with a standard curve generated for each experimental replicate. Data analysed by 2-way ANOVA with Bonferroni post-hoc test, to compare hCG-stimulated or basal cell viability against glyphosate dose, and difference from control shown; $\mathrm{p}<0.01^{* *}, \mathrm{p}<0.001^{* * *}$.

These in vitro cell culture systems did not model in vivo absorption, distribution, metabolic or excretory parameters, nor the regulation of serum carrier and binding proteins. The concentration of FCS (10\%) used in the present study was too low to model the $100 \%$ equivalent concentration of serum components in vivo, but was used to allow comparison with other cell culture studies. The inclusion of $10 \%$ serum in vitro delayed the toxic effects of Roundup by approximately $24 \mathrm{~h}$ previously [6], and in the present study (Table 1). In acute exposures therefore, increasing serum concentrations in vitro decreases the toxic effects of Roundup.

The data from our study confirmed previous observations [21] that glyphosate caused cytotoxicity at concentrations at least two orders of magnitude higher than the equivalent concentration of glyphosate in Roundup (Table 1). The cytotoxicity EC50 values for a range of cell lines exposed to glyphosate for 18-24h in vitro ranged from 16 to 37 $\mathrm{mM}$, whereas exposure to the same concentration of glyphosate in a Roundup formulation (with $7.2 \mathrm{~g} / \mathrm{L}$ glyphosate in the parent solution) generated EC50 values ranging from 0.002 to $0.38 \mathrm{mM}$ (Table 1). The EC50 values for cells exposed to Roundup with $360 \mathrm{~g} / \mathrm{L}$ in the parent solution for $24 \mathrm{~h}$ ranged from 0.13 to $27.6 \mathrm{mM}$ (Table 1). The EC50 values for Roundup spanned two orders of magnitude, whereas the differences in cell lines and culture conditions had less effect on the glyphosate EC50 values; observations partially explained by the membrane-disrupting mechanism of action of Roundup. The data in Table 1 support the proposal that when serum is present in vitro, increasing $\mathrm{pH}$ from acidic to neutral physiological levels further decreases Roundup cytotoxicity.

In initial experiments the presence of cAMP appeared to increase JAr cell sensitivity to Roundup when measured by both MTT assay and progesterone synthesis (Table 1 ) after a $24 \mathrm{~h}$, but not a $72 \mathrm{~h}$ exposure. When this was examined in more detail by exposing cells to Roundup and hCG for shorter exposure periods however, it was found that hCG did not affect the cytotoxicity of Roundup. The EC50 values for cytotoxicity were similar for hCG and its secondary messenger molecule cAMP, as might be expected.

The LH/hCG transduction molecule cAMP also stimulated progesterone synthesis as expected. Walsh et al. (2000) demonstrated that cAMP upregulated the StAR protein which increased progesterone production, and that low non-cytotoxic concentrations of Roundup inhibited cAMP-stimulated StAR upregulation, and caused associated decreases in progesterone production [3]. In our study however, the inhibition of cAMP-stimulated progesterone synthesis occurred at higher, cytotoxic concentrations of Roundup. These data suggest that the two formulations of Roundup that we tested did not act directly on the StAR protein when they were tested at physiological $\mathrm{pH}$ and in the presence of serum, but that the reductions in both basal and cAMP-stimulated progesterone synthesis were caused by the loss of viable steroidogenic cells. In our study, the inhibition of progesterone secretion did not precede cytotoxicity, and endocrine disruption effects were a consequence of cell death. Others have demonstrated that Roundup downregulated P450 arom expression and activity [8] in low non-physiological $\mathrm{pH}$ and serum-free in vitro culture conditions, but the synthesis of estradiol at physiological $\mathrm{pH}$ and in the presence of serum has not yet been examined. Given this lack of data, the proposal that Roundup has endocrine disrupting activity independent of its cytotoxic activity, needs further study.

Previously, a short two hour exposure to Roundup generated a higher EC50 value $(0.14 \mathrm{mM})$ for progesterone synthesis [3] than our longer $24 \mathrm{~h}$ exposure $(0.012 \mathrm{mM})$. The presence of serum in our culture system probably reduced the toxicity of Roundup and in this way caused the lower EC50 value. In our study, the EC50 value for progesterone synthesis was higher than for cytotoxicity (Table 1), indicating that the significant decreases in progesterone concentrations were caused by reduced numbers of viable cells.

The two Roundup formulations selected for examination in this study are available for purchase from local supermarkets for use in domestic gardens. Members of the public may be exposed to these formulations of Roundup by aerosol or dermal contact, for perhaps 1-2 hours, at relatively low frequencies of perhaps 2 to 8 times per year, and the effect of these exposures on healthy adults who use Roundup domestically are not known. It is possible that children, pregnant 
Table 1. Roundup and Glyphosate EC50 values for cytotoxicity and progesterone synthesis in vitro.

\begin{tabular}{|c|c|c|c|c|c|}
\hline Cell Line & $\begin{array}{l}\text { Culture conditions, exposure, } \mathrm{pH} \& \\
\text { FCS }\end{array}$ & $\begin{array}{l}\text { Concentration of Glyphosate } \\
\text { in the Roundup Formulation }\end{array}$ & $\begin{array}{l}\text { EC50 Glyphosate } \\
(\mathrm{mM})\end{array}$ & $\begin{array}{l}\text { EC50 same concentration } \\
\text { of Glyphosate in Roundup } \\
(\mathrm{mM})\end{array}$ & Reference \\
\hline \multicolumn{6}{|c|}{ Cytotoxicity measured in an MTT mitochondrial succinate dehydrogenase assay. } \\
\hline JEG3 & Serum-free, $\mathrm{pH} 5.8,18 \mathrm{~h}$ & $360 \mathrm{~g} / \mathrm{L}$ & 25.2 & 4.2 & Richard, 2005 \\
\hline JEG3 & $10 \%$ FCS, pH 5.8, $18 \mathrm{~h}$ & $360 \mathrm{~g} / \mathrm{L}$ & 27.3 & 16.8 & Richard, 2005 \\
\hline JEG3 & $10 \%$ FCS, pH 5.8, 24h & $360 \mathrm{~g} / \mathrm{L}$ & 37.2 & 27.6 & Benechour, 2007 \\
\hline HEK293 & $10 \%$ FCS, pH 5.8, 24h & $360 \mathrm{~g} / \mathrm{L}$ & 34 & 17 & Benechour, 2007 \\
\hline JEG3 & Serum-free, $\mathrm{pH}$ na, $24 \mathrm{~h}$ & $360 \mathrm{~g} / \mathrm{L}$ & $\sim 7.56$ & na & Mesnage, 2013 \\
\hline JEG3 & Serum-free, $\mathrm{pH} 5.8,24 \mathrm{~h}$ & $7.2 \mathrm{~g} / \mathrm{L}$ & $\sim 42.6$ & $\sim 0.38$ & Benechour, 2009 \\
\hline JEG3 & Serum-free, $\mathrm{pH} 5.8,24 \mathrm{~h}$ & $360 \mathrm{~g} / \mathrm{L}$ & $\sim 42.6$ & $\sim 6.39$ & Benechour, 2009 \\
\hline $\mathrm{JAr}$ & $10 \%$ FCS, pH 7.4, 24h & $7.2 \mathrm{~g} / \mathrm{L}$ & $>4.26$ & 0.008 & Present study \\
\hline $\mathrm{JAr}$ & $10 \%$ FCS, pH 7.4, 24h, +cAMP & $7.2 \mathrm{~g} / \mathrm{L}$ & $>4.26$ & 0.005 & Present study \\
\hline $\mathrm{JAr}$ & $10 \%$ FCS, pH 7.4, 72h & $7.2 \mathrm{~g} / \mathrm{L}$ & $>4.26$ & 0.0017 & Present study \\
\hline $\mathrm{JAr}$ & $10 \%$ FCS, pH 7.4, 72h, +cAMP & $7.2 \mathrm{~g} / \mathrm{L}$ & $>4.26$ & 0.0017 & Present study \\
\hline $\mathrm{JAr}$ & $10 \% \mathrm{FCS}, \mathrm{pH} 7.4,1 \mathrm{~h},+\mathrm{hCG}$ & $7.2 \mathrm{~g} / \mathrm{L}$ & na & 0.319 & Present study \\
\hline $\mathrm{JAr}$ & $10 \%$ FCS, pH 7.4, 4h, + hCG & $7.2 \mathrm{~g} / \mathrm{L}$ & na & 0.099 & Present study \\
\hline $\mathrm{JAr}$ & $10 \% \mathrm{FCS}, \mathrm{pH} 7.4,24 \mathrm{~h},+\mathrm{hCG}$ & $7.2 \mathrm{~g} / \mathrm{L}$ & na & 0.007 & Present study \\
\hline $\mathrm{JAr}$ & $10 \%$ FCS, pH 7.4, 48h, + hCG & $7.2 \mathrm{~g} / \mathrm{L}$ & na & 0.004 & Present study \\
\hline $\mathrm{JAr}$ & $10 \%$ FCS, pH 7.4, 24h & $360 \mathrm{~g} / \mathrm{L}$ & 16 & 0.13 & Present study \\
\hline \multicolumn{6}{|c|}{ Progesterone secretion by Roundup \& Glyphosate exposed cells } \\
\hline MA10 & Serum-free, $\mathrm{pH}$ na, $2 \mathrm{~h}$ & $180 \mathrm{~g} / \mathrm{L}$ & $>0.6$ & 0.14 & Walsh, 2000 \\
\hline $\mathrm{JAr}$ & $10 \%$ FCS, pH 7.4, 24h & $7.2 \mathrm{~g} / \mathrm{L}$ & $>4.26$ & 0.012 & Present study \\
\hline $\mathrm{JAr}$ & $10 \%$ FCS, pH 7.4, 24h, +cAMP & $7.2 \mathrm{~g} / \mathrm{L}$ & $>4.26$ & 0.005 & Present study \\
\hline $\mathrm{JAr}$ & $10 \%$ FCS, pH 7.4, $72 \mathrm{~h}$ & $7.2 \mathrm{~g} / \mathrm{L}$ & $>4.26$ & 0.007 & Present study \\
\hline $\mathrm{JAr}$ & $10 \%$ FCS, pH 7.4, 72h + cAMP & $7.2 \mathrm{~g} / \mathrm{L}$ & $>4.26$ & 0.008 & Present study \\
\hline $\mathrm{JAr}$ & $10 \%$ FCS, pH 7.4, 24h & $360 \mathrm{~g} / \mathrm{L}$ & 26 & 0.2 & Present study \\
\hline
\end{tabular}

JEG and JAr cell lines both derived from human placental choriocarcinoma. HEK- human embryonic kidney cells. MA10 - mouse leydig cell line. FCS - foetal calf serum, >mM - no effect found at the highest concentration tested. na - information not available.

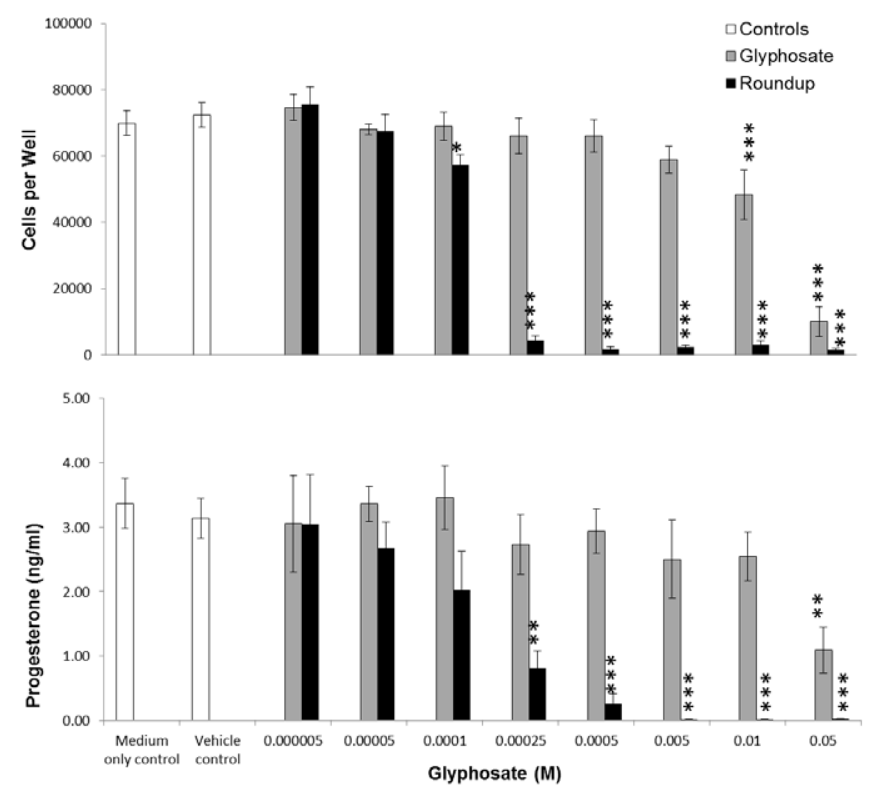

Figure 4. Effect of Glyphosate or Roundup $(320 \mathrm{~g} / \mathrm{L})$ on JAr cell viability and Progesterone Synthesis.

Human JAr cells (40000 per well) were exposed to glyphosate ( $\square$ ) or Roundup ( formulation contained $320 \mathrm{~g} / \mathrm{L}$ glyphosate) in triplicate wells in 96 well plates on 7 separate occasions $(\mathrm{n}=7)$ for $24 \mathrm{~h}$. The mean \pm stdev numbers of surviving cells in each well were determined in an MTT assay, by comparison with a standard curve generated for each experimental replicate. The progesterone secreted into the culture media was measured in an ELISA. Data analysed by 1-way ANOVA with Tukey post-hoc test., and difference from vehicle control (97\% RPMI medium) shown; $\mathrm{p}<0.05^{*}, \mathrm{p}<0.01^{* *}, \mathrm{p}<0.001^{* * *}$. women, the elderly and those suffering chronic illnesses, may be more vulnerable to environmental toxic insults such as that caused by exposure to Roundup sprays than the general population. Irrespective of public exposures, the Australian Drinking Water Guideline (2011) for glyphosate is $0.0059 \mathrm{mM}$, and is based on the premise that an adult of average weight who drinks $2 \mathrm{~L}$ of water a day would not be harmed if the water contained $0.0059 \mathrm{mM}$ glyphosate [22]. The ADWG (2011) notes that 'excursions above this level would need to occur over a significant period to be of health concern, as the health-based guideline is based on long-term effects' [22]. The in vitro EC50 values for glyphosate alone are two or three orders of magnitude higher than this Guideline level (Table 1), and originally justified the use of this concentration, but in our study the $24 \mathrm{~h}$ basal in vitro EC50 value for glyphosate in Roundup formulation was $0.008 \mathrm{mM}$, and in the presence of the cAMP was $0.005 \mathrm{mM}$. Cell lines are less sensitive than primary derived cells such as the epithelial cells lining the gastrointestinal (GI) tract, and low $\mathrm{pH}$ conditions such as those found in the upper GI tract increase Roundup cytotoxicity. Both of these factors may therefore increase the toxicity of Roundup in vivo. Conversely, Glyphosate has low absorption from the GI tract (30-36\%) in rats and rabbits, and the higher proportion of serum constituents in vivo may reduce Roundup toxicity. Seralini et al. (2014) demonstrated that $50 \mathrm{ng} / \mathrm{L}$ Roundup in drinking water had toxic effects in a $2 y$ in vivo study [24], which constitutes a study of long term effects, but at concentrations much lower than the $1 \mathrm{mg} / \mathrm{L}$ Australian Drinking Water Guideline.

In Australia and other countries, drinking water is commonly produced by chlorination of supplies from protected catchments, and/or by Dissolved Air Flocculation and Filtration followed by chlorination, but it is not clear how efficiently these process remove the adjuvants found in Roundup, nor if the specific surfactants and other 
adjuvants comprising the different formulations of Roundup persist into the public water supply. It is also not known whether the chronic toxic effects seen in vivo [24] were caused by the supposedly inert surfactant components of Roundup, or the combination of Roundup surfactants with glyphosate. In the absence of robust data it would be prudent to consider the possibility that Roundup surfactants may be found in drinking water that also contains glyphosate, and to evaluate these mixtures in vivo, in order to assess the continuing relevance of the $1 \mathrm{mg} / \mathrm{L}$ Glyphosate Drinking Water Guideline level. There is clearly a need to conduct in vivo studies to determine the acute and chronic toxicity of glyphosate in domestic Roundup formulations, in order to ensure that existing drinking water guidelines are safe.

\section{Conclusion}

Glyphosate alone is less toxic than glyphosate in a Roundup formulation; both glyphosate and Roundup caused cell death which resulted in decreased progesterone levels in vitro, and endocrine disruption did not precede cytotoxicity. A 24h exposure to a concentration of Glyphosate (in Roundup) similar to that recommended as an acceptable level for Australian drinking water caused significant cytotoxicity in vitro, which supports a call for in vivo studies to characterise the toxicity of Roundup.

\section{Acknowledgement}

We are extremely grateful to Dr. Alison Bleaney, Dr. Marcus Scammall and Environment Tasmania for funding part of this work. We are delighted to acknowledge the enthusiastic technical support provided by the undergraduate and Masters of Biotechnology Studies students of the Medical Biotechnology BTEC3002/9003 topics at Flinders University, who exposed the JAr cells to glyphosate or the 320 $\mathrm{g} / \mathrm{L}$ Roundup formulation in vitro, and conducted the MTT assays and progesterone ELISAs as part of a laboratory practical exercise.

\section{References}

1. Diamanti-Kandarakis E, Bourguignon JP, Giudice LC, Hauser R, Prins GS, et al. (2009) Endocrine-disrupting chemicals: an Endocrine Society scientific statement. Endocr Rev 30: 293-342. [Crossref]

2. Manna PR, Stocco DM (2005) Regulation of the Steroidogenic Acute Regulatory Protein Expression: Functional and Physiological Consequences. Current Drug Targets-Immune, Endocrine \& Metabolic Disorders 5: 93-108. [Crossref]

3. Walsh LP, McCormick C, Martin C, Stocco DM(2000) Roundup inhibits steroidogenesis by disrupting steroidogenic acute regulatory (StAR) protein expression. Environ Health Perspect 108: 769-776. [Crossref]

4. Stocco CO, Deis RP (1999) Luteinizing hormone inhibits conversion of pregnenolone to progesterone in luteal cells from rats on day 19 of pregnancy. Biol Reprod 60: 729732. [Crossref]

5. Young FM, Micklem J, Humpage AR (2008) Effects of blue-green algal toxin cylindrospermopsin (CYN) on human granulosa cells in vitro. Reprod Toxicol 25: 374380. [Crossref]

6. Richard S, Moslemi S, Sipahutar H, Benachour N, Seralini GE (2005) Differential effects of glyphosate and roundup on human placental cells and aromatase. Environ Health Perspect 113: 716-720. [Crossref]

7. Benachour N, Séralini GE (2009) Glyphosate formulations induce apoptosis and necrosis in human umbilical, embryonic, and placental cells. Chem Res Toxicol 22 97-105. [Crossref]

8. Gasnier C, Dumont C, Benachour N, Clair E, Chagnon MC, et al. (2009) Glyphosatebased herbicides are toxic and endocrine disruptors in human cell lines. Toxicology 262: 184-191. [Crossref]

9. Pattillo RA, Ruckert A, Hussa R, Bernstein R (1971) The Jar Cell Line-Continuous Human Multihormone Production and Controls. In Vitro Abstract 6: 398-399.

10. King A, Thomas L, Bischof P (2000) Cell culture models of trophoblast II: trophoblast cell lines--a workshop report. Placenta 21 Suppl A: S113-119. [Crossref]
11. Serrano MA, Macias RIR, Briz O, Monte MJ, Blazquez AG, et al. (2007). Expression in Human Trophoblast and Choriocarcinoma Cell Lines, BeWo, Jeg-3 and JAr of Genes Involved in the Hepatobiliary-like Excretory Function of the Placenta. Placenta 28: 107-117. [Crossref]

12. Sullivan MH (2004) Endocrine cell lines from the placenta. Mol Cell Endocrinol 228: 103-119. [Crossref]

13. Bahn RS, Worsham A, Speeg KV Jr, Ascoli M, Rabin D (1981) Characterization of steroid production in cultured human choriocarcinoma cells. J Clin Endocrinol Metab 52: 447-450. [Crossref]

14. Edwards V, Benkendorff K, Young F (2014) An in vitro high-throughput assay for screening reproductive and toxic effects of anticancer compounds. Biotechnol Appl Biochem 61: 582-592. [Crossref]

15. Adler RR, Ng AK, Rote NS (1995) Monoclonal antiphosphatidylserine antibody inhibits intercellular fusion of the choriocarcinoma line, JAR Biol Reprod 53: 905-910. [Crossref]

16. Plessinger MA, Miller RK (1999) Effects of zidovudine (AZT) and dideoxyinosine (ddI) on human trophoblast cells. Reprod Toxicol 13: 537-546. [Crossref]

17. Harvey PW, Everett DJ (2003) The adrenal cortex and steroidogenesis as cellular and molecular targets for toxicity: Critical omissions from regulatory endocrine disrupter screening strategies for human health? Journal of Applied Toxicology 23: 81-87. [Crossref]

18. Williams GM, Kroes R, Munro IC (2000) Safety evaluation and risk assessment of the herbicide Roundup and its active ingredient, glyphosate, for humans. Regul Toxicol Pharmacol 31: 117-165. [Crossref]

19. Benachour N, Sipahutar H, Moslemi S, Gasnier C, Travert C, et al. (2007) Time- and dose-dependent effects of roundup on human embryonic and placental cells. Arch Environ Contam Toxicol 53: 126-133. [Crossref]

20. Mesnage R, Bernay B, Séralini GE (2013) Ethoxylated adjuvants of glyphosate-based herbicides are active principles of human cell toxicity. Toxicology 313: 122-128. [Crossref]

21. Mesnage R, Defarge N1, Spiroux de Vendômois J2, Séralini GE1 (2014) Major pesticides are more toxic to human cells than their declared active principles. Biomed Res Int 2014: 179691. [Crossref]

22. Council NHMR (2011) Australian Drinking Water Guidelines 6 National Water Quality Management Strategy. a. t. N. R. M. M. C. National Health and Medical Research Council. Canberra.

23. Séralini GE, Clair E, Mesnage R, Gress S, Defarge N, et al. (2012) Long term toxicity of a Roundup herbicide and a Roundup-tolerant genetically modified maize. Food Chem Toxicol 50: 4221-4231. [Crossref]

24. Séralini GE, Mesnage R2, Defarge N2, Spiroux de Vendômois J3 (2014) Conclusiveness of toxicity data and double standards. Food Chem Toxicol 69: 357-359. [Crossref]

25. Paz C, Cornejo Maciel F, Maloberti P, Walsh LP, Stocco DM, et al. (2002) Protein tyrosine phosphatases are involved in LH/chorionic gonadotropin and 8Br-cAMP regulation of steroidogenesis and StAR protein levels in MA-10 Leydig cells. $J$ Endocrinol 175: 793-801. [Crossref]

26. Devoto L, Christenson LK, McAllister JM, Makrigiannakis A, JF Strauss (1999) Insulin and insulin-like growth factor-I and -II modulate human granulosa-lutein cell steroidogenesis: enhancement of steroidogenic acute regulatory protein (StAR) expression. Mol Hum Reprod 5: 1003-1010.

27. Clair E, Mesnage R, Travert C, Séralini GÉ (2012) A glyphosate-based herbicide induces necrosis and apoptosis in mature rat testicular cells in vitro, and testosterone decrease at lower levels. Toxicol In Vitro 26: 269-279. [Crossref]

28. Freshney RI (2005) Culture of Animal Cells: A Manual of Basic Technique, ( $5^{\text {th }}$ Edn), John Wiley and Sons Inc., New Jersey, USA, pp: 346-348; 359-373.

29. Mosmann T (1983) Rapid colorimetric assay for cellular growth and survival application to proliferation and cytotoxicity assays. J Immunol Methods 65: 55-63. [Crossref]

30. Young FM, Phungtamdet W, Sanderson BJ (2005) Modification of MTT assay conditions to examine the cytotoxic effects of amitraz on the human lymphoblastoid cell line, WIL2NS. Toxicol In Vitro 19: 1051-1059. [Crossref]

Copyright: (C2015 Young F. This is an open-access article distributed under the terms of the Creative Commons Attribution License, which permits unrestricted use, distribution, and reproduction in any medium, provided the original author and source are credited. 